\title{
Az alultápláltság előfordulása és a klinikai táplálás lehetőségének vizsgálata csípőtáji sérültekben
}

Elözetes közlemény

\author{
DR. FERDINANDY CSILLA, DR. NARDAI GÁBOR
}

\section{ÖSSZEFOGLALÁS}

A mútéti kezelés sikere számos nem sebészi tényezőtől is függ. Különösen igaz ez egy olyan vulnerábilis betegcsoportban, mint a csípőtáji törés miatt kezelt betegeink. Közismert, hogy a betegek tápláltsági állapota is meghatározó az immunrendszeri múködés, sebgyógyulás, mobilizálhatóság szempontjából, ezért tartottuk fontosnak, hogy megvizsgáljuk, milyen tápláltsági állapotban kerülnek intézetünkbe a csípőtáji törést elszenvedő betegek, és mit tudunk tenni értük a perioperatív szakban. A vizsgálati időszakban intézetünkbe felvett betegek között validált, kérdőíves felméréssel és a biometriai adatok felvételével becsültük meg a tápláltsági rizikót. Az alultáplált betegeknek magas fehérjetartalmú, orális ivótápszerrel egészítettük ki a kórházi táplálását. Felmérésünk alapján a vizsgált 125 sérült 67\%-a volt magas alultápláltsági rizikójú, míg mindössze 12\%-a bizonyult tápláltsági szempontból kockázatmentesnek. Az ivótápszeres kiegészítés kivitelezhető volt, a betegek és az ápolószemélyzet jól fogadták, bár használata a vizsgálati időszakban még nem volt teljes körü. Vizsgálatunk célja felhívni a figyelmet arra, hogy hazánkban a csípőtáji törés miatt felvett betegek között igen gyakori a malnutríció, így ezeket a betegeket szűrni kell, és amenynyiben indokolt, meg kell kezdeni a kórházi étrend tápszeres kiegészítését.

\section{Kulcsszavak: $\quad$ Alultápláltság; Csípötáji törések; Klinikai táplálás; Malnutríció; Posztoperativ gondozás; Táplálék-kiegészítök;}

Cs. Ferdinandy, G. Nardai: Survey of malnutrition and possibilities of clinical nutrition among patients admitted with hip fracture. Preliminary report

Success of the surgical treatment depends on many non-surgical factors. This is extremely true on such a vulnerable patient population as hip fracture patients. It is well known that immune function, wound healing and mobilisation are all influenced by the nutritional status, thus we decided to perform a survey of nutritional risk of hip fracture patient and to determine the possibilities of clinical nutritional support in perioperative settings. Within the study period a validated questionnaire and measurement of biometric data were used to estimate nutritional risk. Patients with high malnutrition risk were supplied with protein and calorie rich oral feeding formula (drink). Nutritional status of 125 patients was screened during the study period and $67 \%$ of them had a high malnutrition risk. Only $12 \%$ of the population was without any nutritional risk factors. Supply, intake and acceptance of the supplementary oral feeding formula were favourable among patients and nurses, although implementation to the daily practice was not general during the survey. These results draw our attention to the high risk of malnutrition among hip fracture patients, this screening and, if malnutrition is proven, feeding of these patients is important.

\section{Keywords:}




\section{BEVEZETÉS}

A csípőtáji törés mútéti ellátása a baleseti sebészeti osztályok egyik leggyakoribb feladata, s ez a törés az egyik leggyakoribb fatális kimenetelű sérülés is egyben. Népegészségügyi jelentőségét az is kiemeli, hogy évente a csípőtáji sérültek több kórházi ápolási napot igényelnek, mint az összes többi vázizomrendszeri sérült együttvéve. A csípőtáji sérültek ellátása és kezelése jelentős egészségügyi kiadással is jár (például az USA-ban évente 9.8 milliárd dollárba kerül) $(1,6,12)$.

Ráadásul az ilyen műtétek után a várható korai (30 napon belüli) halálozás igen magas, meghaladhatja a $10 \%$-ot is (5) (saját, nem közölt adataink szerint a Baleseti Központban 10,5\% - „A mútéti ellátásra kerülő csípőtáji töréssel felvett betegek kimenetele kórházunkban - belső audit, Nardai G. 2010)! Ez az igen magas mútét utáni halálozás természetesen elsősorban nem a nagy mútéti megterhelés, a sebészi invázió következménye, hanem a csípőtáji törést elszenvedő betegek gyenge egészségügyi állapotával, csökkent biológiai tartalékaival magyarázható. Ezért is kell tisztában lennünk azzal, hogy melyek azok a lehetőségek, amelyek segítségével, a megfelelő mútéti technika és implantátumválasztás mellett javíthatunk a gyógyulás esélyein, és csökkenteni tudjuk a csípőtáji sérüléshez társuló igen magas morbiditást és halálozást. A szakirodalom számos tényezőt sorol fel, ilyenek a korai mobilizálás, fizioterápia, a tartós hólyagkatéterezés elkerülése, az adekvát fájdalomcsillapítás, a komplex, korai rehabilitáció és ilyen a klinikai táplálásterápia is (10)! Ez utóbbi jelentőségére növekvő számú közlemény hívja fel a figyelmet, kiemelve, hogy az alultáplált betegek aránya ebben a betegcsoportban igen magas, akár $70-80 \%$ is lehet (4)! Nem meglepő ez, hiszen a csípőtáji sérültek többsége idős, egyedül vagy éppen ápolási otthonban él, szociálisan-fizikailag csökkent aktivitású és ezek mind az alultápláltság kockázati tényezői is. Tegyük hozzá, hogy praktikusan nem ismerünk olyan betegséget, amelyben az éhezés előnyös lenne, különösen igaz ez a sérülések, illetve mútétek utáni, nagy energiaigényű időszakra. Az alultápláltság, különösen az elégtelen fehérjebevitel elhúzódó seb- és törésgyógyuláshoz, gyakoribb fertőzéses komplikációkhoz, felfekvések kialakulásához vezet. Ezzel párhuzamosan természetesen növekszik a kórházi ellátás ideje és költsége is. Csak néhány példa a sok közül: az USA-ban 18 milliárd USD összeget (a teljes egészségügyi költség 10\%-át!) jelent a kóros tápláltsági állapot okozta többletköltség (2); az Egyesült Királyságban a közepes és magas rizikójú betegek esetében a betegségekhez kapcsolódó ma!nutrícióbó! származó többletköltség éves szinten körülbelül 7,3 milliárd GBP (kb. 10,5 milliárd EUR) volt. Ezen öszszeg több mint felét a hospitalizációs költségek emésztették fel (11).

A tápláltsági állapot szűrésének és szükség esetén a klinikai táplálás megkezdésének jelentőségét minden a csípőtáji törésben szenvedő betegek ellátásával foglalkozó ajánlás és összefoglaló kiemeli. Ezek nem bonyolult eljárások, a felmérés egy rövid, validált kérdőív segítségével, válogatott esetekben néhány olcsó laboratóriumi vizsgálattal elvégezhető. A posztoperatív szakban szükséges, magas fehérje- és kalóriatartalmú tápszer per os jól fogyasztható formában rendelkezésre áll, teljes táplálásként vagy táplálás kiegészítésként is megadható. Bár hazánkban a malnutrícióval veszélyeztetett fekvőbetegek aránya megegyezik a nemzetközi átlaggal, az egy före jutó enterális tápszerfogyasztás a nemzetközi átlagnak mégis csupán 10\%-át teszi ki (8) és a klinikai táplálást nem nevezhetjük reflektorfényben álló orvosi tevékenységnek sem.

Hiányosságainkat felismerve hoztuk létre a Baleseti Központban a Klinikai Táplálási Munkacsoportot 2013 elején. Célunk a veszélyeztetett betegeknél a tápláltsági állapot szúrésének bevezetése mellett az volt, hogy ráirányítsuk a kollégák figyelmét a problémára és elősegítsük az alultáplált betegek felismerését, illetve klinikai táplálásuknak a megindítását. Munkánk részeként felmérést végeztünk a csípőtáji töréssel felvett betegeink körében a tápláltsági állapotuk meghatározására, illetve elkezdtük az ápolók bevonásával az alultáplált betegek klinikai táplálásterápiáját is. Az alábbiakban munkánk kezdeti eredményeiről számolunk be. Egyben keressük annak lehetőségét, hogy akár más, nívós traumatológiai centrumokkal együtt hogyan vizsgálhatjuk szélesebb betegpopuláción a kérdéskört, illetve hogyan követhetnénk a táplálásterápia hatását a betegek túlélésére, életminőségére. 


\section{MÓDSZER}

Obszervációs keresztmetszeti vizsgálat keretében demográfiai és tápláltsági adatokat gyűjtöttünk hetente egyszer 2013 első félévében csípótáji törés (monotrauma) miatt felvett, tiszta tudatú betegek körében, beleegyezésükkel, a felvételüket követő napokban. Az adatgyújtéshez az Európai Táplálási Társaság (ESPEN) Nutrition Risk Screening (NRS-ESPEN, Guideline for Nutrition Screening, 2002) (7) kérdőivét alkalmaztuk a Baleseti Központra adaptált formában (1. ábra). Amikor a beteg testsúlyáról hitelt érdemlő adat nem állt rendelkezésre, ágymérleg hiányában becsült testsúllyal kalkuláltuk a BMI-t, a testmagasságot, körfogatokat mérőszalaggal mértük.

Az NRS kérdőív a beteg BMI értéke, közelmúltban észlelt testsúlyvesztése és étvágyának, táplálékbevitelének csökkenése, illetve az alapbetegség figyelembevételével kalkulálja a tápláltsági kockázatot. Ezt 0-6 pont közötti értékkel jelzi, ahol 3 pont felett már magas alultápláltsági rizikójúnak és táplálásterápiára szorulónak minősül a beteg. A 4-es rizikópont felett álló betegek részére személyre szabott táplálásterápiát indítottunk.

A mesterséges táplálást a normál kórházi diéta („,könnyú-vegyes”: 1800-2000 kcal/nap) mellé adott, magas kalória- (2 kcal/m!) és fehérjetartalmú $(1,5 \mathrm{~g} / \mathrm{ml})$ ivótápszerrel végeztük a posztoperatív szakban, napi $2-3 \times 200 \mathrm{ml}$-es kitűzött célmennyiséggel. A táplálásterápia bevezetésének hatékonyságát, az osztályok által a csípőtáji töréssel kezelt betegek számára igényelt ivótápszer mennyiségének változásával követtük.

A vizsgált populációt jellemző adatokat átlag士szórás, illetve előfordulásuk százalékos arányában tüntettük fel.

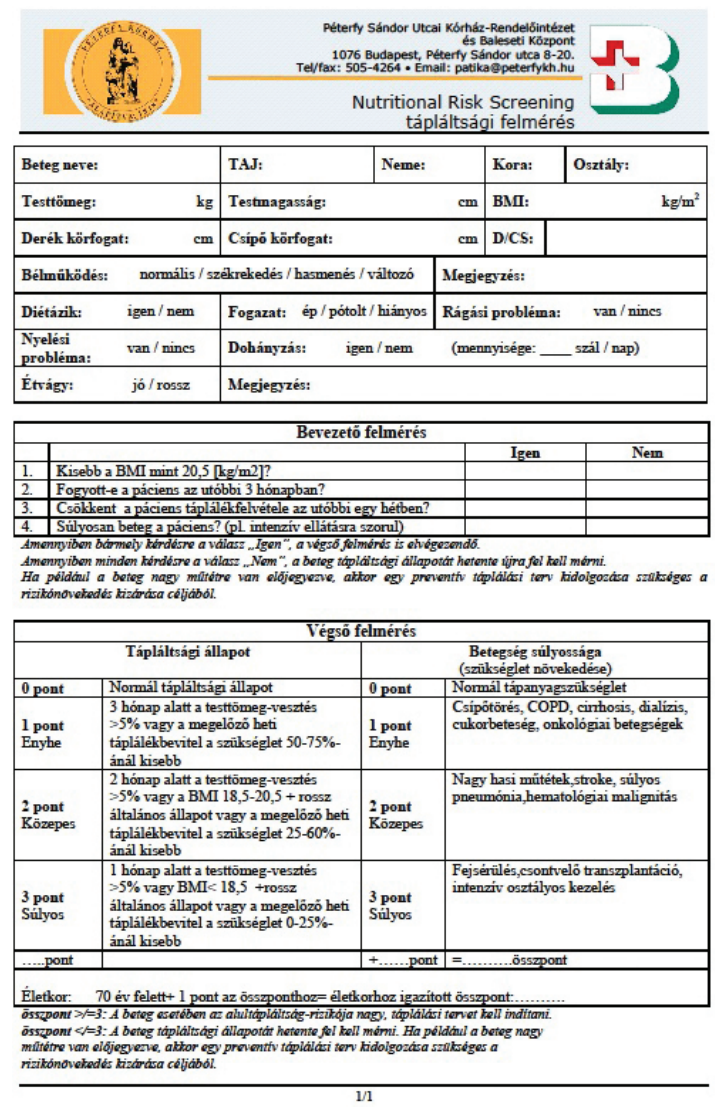

1. ábra Tápláltsági rizikófelmérō kérdőív (NRS-BK) 


\section{EREDMÉNYEK}

A vizsgálatba 125 fő (96 nő és 29 férfi) került bevonásra, átlagéletkoruk $76 \pm 14$ év volt. Kétharmaduk tomportáji töréssel került felvételre. Ez az adott időszakban csípőtáji töréssel felvett összes beteg mintegy $20 \%$-a volt, a töréstípus megoszlása szempontjából az arány az egész populációt tekintve azonos volt (tomportáji: 66,4\%, combnyak 33,6\%). A táplálkozást befolyásoló egyéb jellemzők közül említésre méltó a fogazat hiányának, az állandó vagy rendszeres obstipáció előfordulásának magas aránya (25-25\%), illetve a rendszeres dohányzók aránya (17\%) a vizsgált populációban (I. táblázat).

A kérdőíves felmérés alapján a felmért populáció $67 \%$-a volt malnutríció tekintetében magas rizikójú (NRS>3 pont), aki igényelte a klinikai táplálásterápia elindítását. További 21\%-uk tápláltsági állapota rendszeres megfigyelést igényelt, 12\%-uk pedig nem szorult táplálék kiegészítésre (NRS=0) (2. ábra). A magas rizikójú betegek közül 42-nek rizikópontja 5, míg 38 főnek 4, négy betegnek pedig 3 volt. A vizsgált populációban a leggyakoribb alultápláltsági rizikófaktorok az alacsony BMI (80\%), az elmúlt hónapokban csökkent étvágy (74\%), a beteg által jelzett fogyás (60\%), illetve a 70 év feletti életkor (56\%) voltak (3. ábra). A kórosan alacsony BMI előfordulása a nőbetegek között magasabb volt (84 vs. $68 \%$ ).

A rizikófelmérés alapján alultáplált betegek kiegészítő per os táplálásához az intézeti gyógyszertár biztosította a beteg igényeihez igazított minőségú és mennyiségű (íz, fehérje- és kalóriatartalom) ivótápszert. Egyéb végpontok (testsúly, albuminszint, klinikai kimenetel) felmérésére a rövid utánkövetési idő miatt csak a beteg viszonylag rövid kórházi benntartózkodási ideje alatt volt lehetőségünk. A tápszeres kiegészítés kapcsán az ápolók és a betegek részéről is egyaránt pozitív visszajelzések érkeztek, a betegek szívesen fogadták és fogyasztották a tápszereket, még nyelési, rágási problémák esetén is (személyes közlések). A tápszert kapó betegek úgy érezték, hogy annak elfogyasztásával ők is tesznek valamit gyógyulásukért, kórházi elbocsátásukat követően recepttel láttuk el őket, így a táplálásterápiát az otthoni lábadozásuk ideje alatt is tudták folytatni. A tápszerek rendelése, elosztása, rászoruló betegek esetén a kiszolgálás komolyabb ápolói terhelést nem okozott. Ennek ellenére az ivótápszerek rendelése a felmérés első hónapjaiban alig emelkedett (körülbelül 30-50 egység/hó, 1 egység $=200 \mathrm{ml}$ ) majd a 6. hónaptól jelentősen növekedett (180 egység/hó) és ez a következő hónapokban is fennállt (4.ábra).

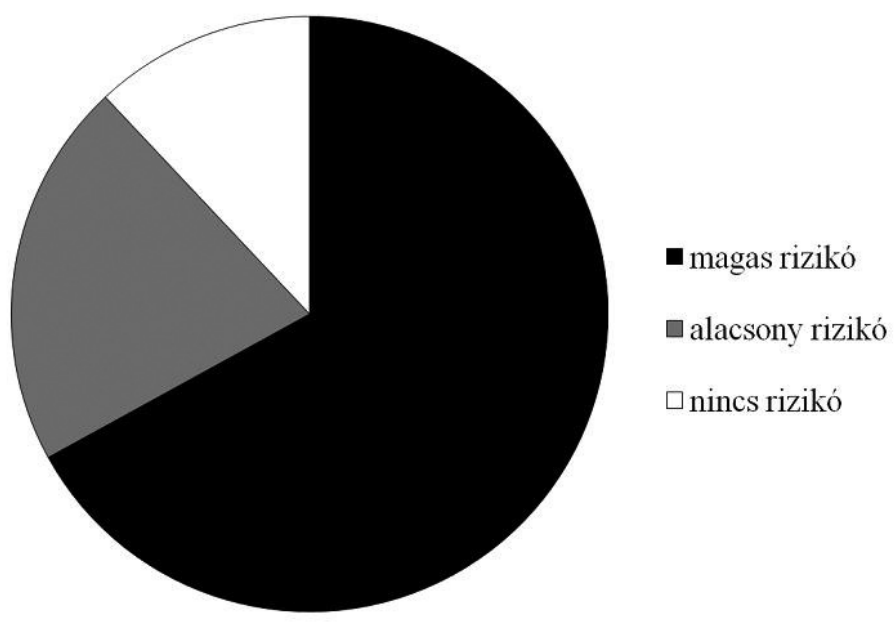

2. ábra Alultápláltsági rizikó megoszlása a vizsgált betegcsoportban ( $n=125)$ 


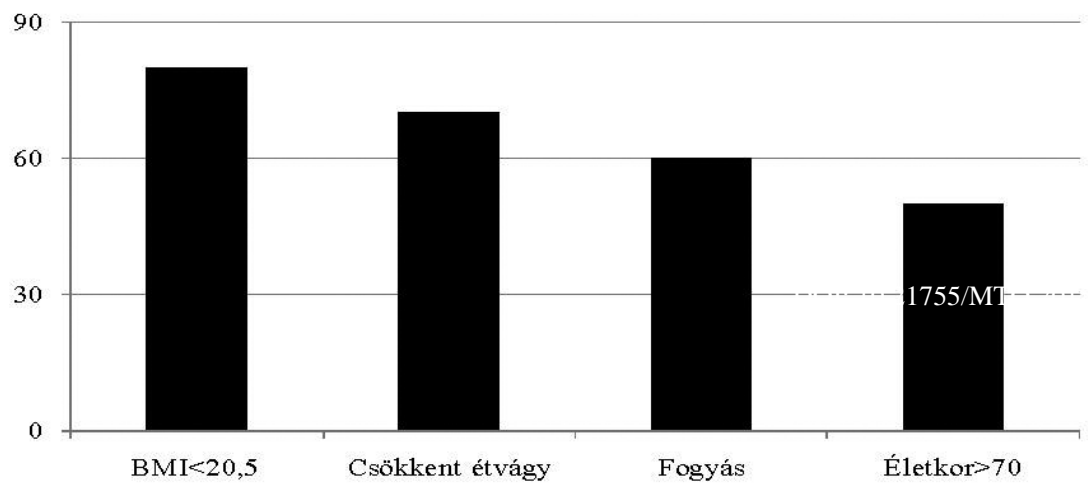

3. ábra Alultápláltsági rizikófaktorok előfordulása a vizsgált populációban (az összes \%-ában)

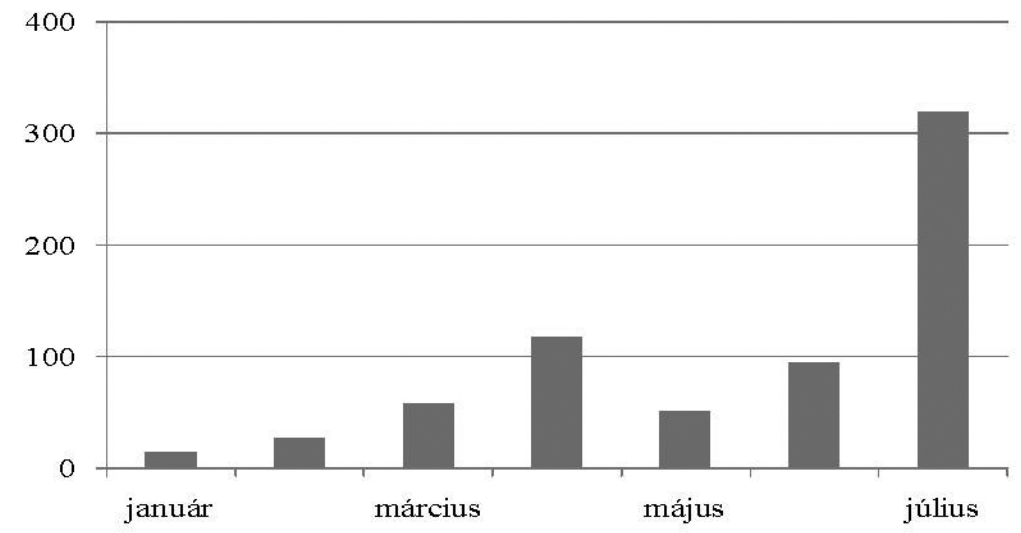

4. ábra Ivótápszer felhasználás a traumatológiai sebészeti-traumatológiai osztályokon (egység/hó) 


\section{I. táblázat Felmért betegcsoport (n=125) adatai}

\begin{tabular}{|c|c|}
\hline Életkor (év) & $76 \pm 14$ \\
\hline Férfiak aránya & $23 \%$ \\
\hline Törés típusa & $62,5 \%$ per/subtrochanter törés \\
& $37,5 \%$ combnyaktörés \\
\hline Fogazat & $24 \%$ hiányos \\
& $56 \%$ pótolt \\
\hline Dohányzik & $17 \%$ \\
\hline Obstipáció & $25 \%$
\end{tabular}

\section{MEGBESZÉLÉS}

Vizsgálatunk igazolta, hogy a csípőtáji töréssel felvett sérültek között igen magas az alultápláltság miatt veszélyeztetett betegek aránya! Ez részben azzal is magyarázható, hogy az alultáplált, vagy obes, de szarkopéniás betegek mozgékonysága csökken, így az elesés, a következményes csípőtáji törések gyakorisága nagyobb. Az alultápláltság mutatói közül a leggyakrabban az alacsony BMI, majd az étvágy-táplálékbevitel csökkenése fordult elő. Fontos megjegyeznünk, hogy az alultápláltsági rizikófaktorok jelenléte nem azonos a klinikailag jelentős alultápláltsággal, de minél magasabb ez a rizikó, a kezelés kimenetelét valóban befolyásoló tápláltsági hiányállapot fennállása annál valószínúbb. Az egyes rizikófaktorok felmérésével kapcsolatban említhetünk nehézségeket. Bár a BMI meghatározó érték az alultápláltsági rizikó felmérésében, megbízható felmérése problémás lehet. Az önbevalláson alapuló adatok esetében gondot jelenthet, hogy a beteg nem rendelkezik aktuális adatokkal testsúlyát, magasságát illetően, vagy azokat hibásan közli, illetve mind a súly, mind a magasságmérés az ágyban fekvő, friss törés vagy mútét miatt immobilizált betegeknél egyszerű módon nem kivitelezhető. $A z$ étvágycsökkenés megítélésének is megvannak a korlátai, ráadásul szubjektív paraméter, de sokszor mégis megbízhatóbban felmérhető, mint például a testsúlyvesztés, ami rendszeres mérést feltételez. Az étvágycsökkenés gyakorisága mögött az áll, hogy az idősebb populációban a hajlamosító tényezők (például szociális izoláció, íz érzés csökkenése, rágásfogazat romlása, szűkösebb anyagi helyzet, főzés, önellátás nehézségei) előfordulása is egyre gyakoribb. A felmérés korlátai ellenére a klinikailag jelentős alultápláltsági rizikó magas (67\%!) előfordulási arányát valósnak tartjuk. Adatainkat a külföldi felmérések hasonló adatai is igazolják (5). A jelentős alultápláltság gyakorisága a csípőtáji törést elszenvedett betegek populációjában azért sem meglepő, hiszen a két kórállapot predisponáló tényezői részben közösek. A 70 év feletti életkor, az inaktivitás, az ápolási otthonokhoz kötődő életmód, bizonyos gyógyszerek szedése, a demencia, az alkoholbetegség, az érzékszervi problémák mind a csípőtáji törésnek, mind a malnutríciónak rizikófaktorai. Ezért is indokolt különösen ebben a betegcsoportban a malnutrícióra való odafigyelés, a tápláltsági állapot szűrése.

Nem elég azonban felismerni az alultápláltság veszélyét, de a posztoperatív komplikációk csökkentése érdekében mielőbb el kell kezdeni a megfelelő táplálásterápiát is. Optimális esetben azt hetekkel a mútét előtt lenne jó elkezdeni, de csípőtáji törés esetén ezt nyilvánvalóan nem jön szóba, így marad a posztoperatív szak. Az alultáplált, különösen a szarkopéniás, mútéten átesett betegek számára a magas fehérjetartalmú ( $\mathrm{kb} .1,5 \mathrm{~g}$ fehérje/kg/nap), kalóriadús (22-25 $\mathrm{kcal} / \mathrm{kg} /$ nap), vitaminok és nyomelemek tekintetében is kiegyensúlyozott összetételü étrendtől várható kedvező hatás. Elvben ez egyéni konyhai menüvel is megvalósítható lenne, de a sokféle szakmai és minőségi elvárásnak, különösen hazai viszonyok között a kórházi konyhák megfelelni nem tudnak. Optimális megoldás azonban olyan gyári tápszerek bevezetése a klinikai táplálásba, amelyek a fenti, összetételbeli kívánalmaknak is megfelelnek, különböző ízekben, könnyen fogyasztható állagban és 
kiszerelésben elérhetőek. Ezek teljes enterális táplálásra is alkalmasak, de legtöbbször kiegészítő tápszerként is elegendő a használatuk a normál kórházi konyhai diéta mellett. Előnyük továbbá, hogy fogyasztásuk ápolói segítséget sokkal kevésbé igényel, mint a normál koszt és hatékonyságuk ezen a betegcsoporton is bizonyított (3). Saját gyakorlatunkban is ezek alkalmazását vezettük be.

A Baleseti Központban havonta 110-130 csípőtáji törést elszenvedett beteg kerül, túlnyomó többségük mútéti ellátásban részesül. Ezek szerint és a felmért alultápláltsági gyakoriság alapján a kalkulált tápszerigény intézetünkben 800-1000 × $200 \mathrm{ml}$ lenne havonta. A felmérés időszakában, bár a traumatológiai osztályokról érkező tápláltsági szúrés jelentések és tápszer igények száma egyértelmű növekedést mutatott, de mégis elmaradt a számított értéktől (max. 320 db/hó). Ezek az eredmények arra utalnak, hogy számos csípótáji törés miatt felvett betegünk alultáplált állapota még nem került felismerésre, illetve nem indult klinikai táplálásterápia ott, ahol indokolt lenne. Ezen az ellátó személyzet képzésével és a tápláltsági állapotszűrés és jelentés általánossá tételével is igyekszünk javítani! Segítségünkre van ebben a munkánkban, hogy a probléma fontosságát felismerve azóta a tápláltsági szűrés validált kérdőívvel történő felmérését és a kiegészítő táplálásterápia elindítását intézetvezetői utasítás teszi szükségessé ebben a betegcsoportban.

Munkánk üzenete az is, hogy klinikai táplálási munkacsoport hazai körülmények között is minimális anyagi ráfordítással megszervezhető és múködtethető. A hatékony klinikai táplálás haszna rövidtávon sokszor nem mérhető, de több költséghatékonysági tanulmány igazolja egyértelmű hosszú távú előnyét (9)! A munkacsoport energiáit célzottan a rizikócsoportok felismerésére és ellátására fordítva érdemi eredményeket érhetünk el itthon is. Bár vizsgálatunk nem célozta az eredményesség felmérését, a táplálásterápiában részesülő betegeink adatainak feldolgozásából származó előzetes adataink alapján az antibiotikumigény ebben a betegcsoportban kimutathatóan csökkent. A kollégák visszajelzése alapján a perorális tápszerek jól alkalmazhatóak, a betegek kalóriabevitelét érdemben javították. Lényeges sikernek értékeljük továbbá azt is, hogy maguktól a betegektől is igen pozitív visszajelzéseket kapunk, sok esetben az intézetből való távozás után is kérték a tápszerek receptre felírását és otthonukban is folytatták a kiírt táplálásterápiát a mielőbbi felépülés érdekében.

Ezek a tapasztalatok is motiválnak bennünket abban, hogy vizsgálatunkat folytassuk, lehetőség szerint más traumatológiai centrumokkal együttmǘködésben saját adatainkat nagyobb betegpopuláción ellenőrizzük. Fontosnak tartjuk továbbá, hogy a nemzetközi eredményeken túl a posztoperatív szakban bevezetett táplálásterápia hatását hazai utánkövetési eredményekkel is megerősítsük. Ennek keretében nem csak a szövődmények, de az életminőség, a rehabilitációs eredmények és a túlélés is felmérésre kerülhetne és az eredmények a korábbi, hasonló populáción végzett tanulmányok eredményeivel összehasonlíthatóak lennének. Szeretnénk, ha mindezt egy, a hazai viszonyokat jól reprezentáló többcentrumos, obszervációs vizsgálatban, a jövőben megvalósíthatnánk, amihez érdeklődő centrumok jelentkezését szívesen fogadjuk!

\section{KÖVETKEZTETÉSEK}

Vizsgálatunk igazolta, hogy a hazai csípőtáji sérültek körében is igen gyakori a táplálásterápiát szükségessé tevő, súlyos alultápláltság, ami a kórházi morbiditás és mortalitás meghatározó tényezője. Fontosnak tartjuk ennek alapján ebben a betegcsoportban a tápláltsági állapot rendszeres szűrését és a magas rizikójú betegek kezelését. Eredményeink és tapasztalataink alapján ebben a csoportban is végezhető alacsony ráfordítással, hatékony klinikai táplálásterápia a posztoperatív szakban perorális ivótápszerek segítségével.

Noha napjainkban egyre több tanulmány foglalkozik a klinikai táplálás jelentőségével, a tapasztalatok mégis azt mutatják, hogy hazánkban még mindig nem kap kellő hangsúlyt a gyógyulásnak eme szerves és nélkülözhetetlen eleme. Örülünk annak, hogy ezen a téren éppen a Baleseti Központban sikerült komoly előrelépést tennünk, ahol évtizedekig volt az Intenzív Betegellátó Osztály vezetője Dr. Varga Péter főorvos úr, aki a klinikai táplálás magyarországi megteremtésének meghatározó egyénisége volt (13). 


\section{IRODALOM}

1. Allander E., Lindahl B. I.: The Mediterranean Osteoporosis Study (MEDOS): theoretical and practical issues of a major international project on hip fracture epidemiology. Bone. 1993. 14. Suppl 1: S37-43.

2. American Society for Parenteral and Enteral Nutrition (A.S.P.E.N.) Board of Directors: Clinical Guidelines for the Use of Parenteral and Enteral Nutrition in Adult and Pediatric Patients, 2009. JPEN J. Parenter. Enteral Nutr. 2009. 33. (3): 255259.

3. Anbar R., Beloosesky Y., Cohen J., Madar Z., Weiss A., Theilla M., Koren Hakim T., Frishman S., Singer P.: Tight calorie control in geriatric patients following hip fracture decreases complications: a randomized, controlled study. Clin. Nutr. 2014. 33. (1): $23-28$.

4. Bell J. J., Bauer J. D., Capra S., Pulle R. C.: Concurrent and predictive evaluation of ivicinutricion diaginjsito measliresi in hip) fracture inpatients: a diagnostic accuracy study. Eur. J. Clin. Nutr. 2014. 68. (3): 358-362.

5. Carpintero P., Caeiro J. R., Carpintero R., Morales A., Silva S., Mesa M.: Complications of hip fractures: A review. World J. Orthop. 2014. 5. (4): 402-411.

6. Haentjens P., Autier P., Barette M., Boonen S., Belgian Hip Fracture Study Group: The economic cost of hip fractures among elderly women. A one-year, prospective, observational cohort study with matched-pair analysis. Belgian Hip Fracture Study Group. J. Bone Joint Surg. Am. 2001. 83-A. (4): 493-500.

7. Kondrup J., Rasmussen H. H., Hamberg O., Stanga Z., Ad Hoc ESPEN Working Group. Nutritional risk screening (NRS 2002): a new method based on an analysis of controlled clinical trials. Clin. Nutr. 2003. 22. (3): 321-336.

8. Lelovics Z., Bozó-Kegyes R., Bonyár-Müller K., Figler M.: Results of nutritional risk screening of patients admitted to hospital. Acta Physiol. Hung. 2008. 95. (1): 107-118.

9. Neelemaat F., Bosmans J. E., Thijs A., Seidell J. C., van Bokhorst-de van der Schueren MA.: Oral nutritional support in malnourished elderly decreases functional limitations with no extra costs. Clin. Nutr. 2012. 31. (2): 183-190.

10. Pedersen S. J., Borgbjerg F. M., Schousboe B., Pedersen B. D., Jørgensen H. L., Duus B. R., Lauritzen J. B., Hip Fracture Group of Bispebjerg Hospital: A comprehensive hip fracture program reduces complication rates and mortality. J. Am. Geriatr. Soc. 2008. 56. (10): 1831-1838.

11. Russell C. A.: The impact of malnutrition on healthcare costs and economic considerations for the use of oral nutritional supplements. Clin. Nutr. Suppl. 2007. 2. (1): 25-32.

12. The Burden of Musculoskeletal Diseases int he United States: Impact of musculoskeletal diseases ont he US economy. Letöltve 2015-06-10 http://www.boneandjointburden.org/2013-report/impact-musculoskeletal-diseases-us-ec

13. Varga P.: A klinikai táplálás elmélete és gyakorlata. Az enterális és parenterális mesterséges táplálás $A B C$-je. Budapest: Melania. 1998.

\section{Dr. Nardai Gábor}

Péterfy Sándor utcai Kórház-Rendelőintézet és Baleseti Központ

1081 Budapest, Fiumei út 17.

Tel.: +36-70-9323236 ; E-mail: nardai@hotmail.com 